ppi $201502 Z U 4645$

Esta publicación cientifica en formato digital es continuidad de la revista impresa ISSN-Versión Impresa 0798-1406 / ISSN-Versión on line 2542-3185Depósito legal pp

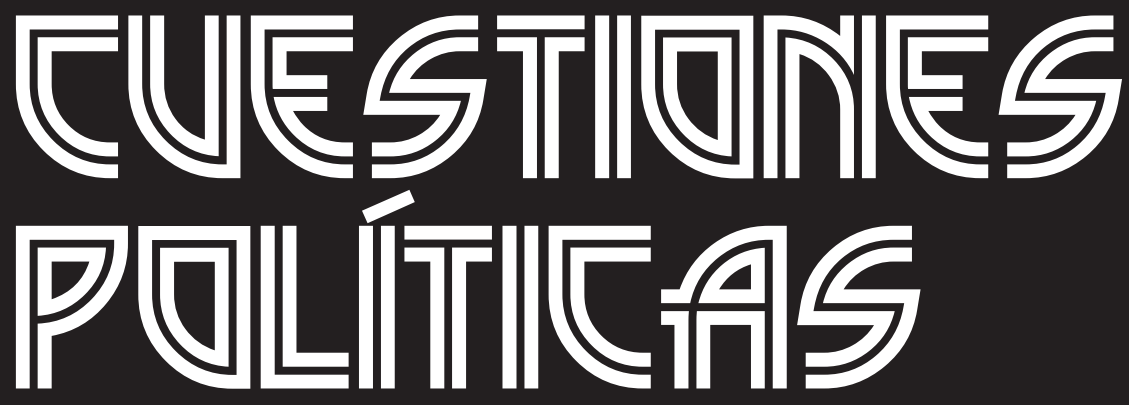

Instituto de Estudios Políticos y Derecho Público "Dr. Humberto J. La Roche' de la Facultad de Ciencias Jurídicas y Políticas de la Universidad del Zulia Maracaibo, Venezuela
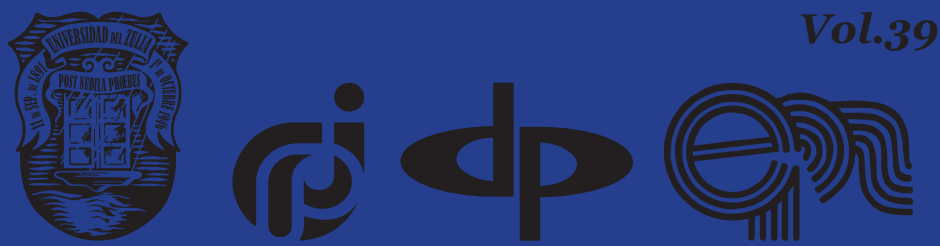


\title{
Principles of Law and Electronic Constitutional (Statutory) Justice in the Constituent Entities of the Russian Federation
}

\author{
DOI: https://doi.org/10.46398/cuestpol.3968.39
}

\author{
Gulnara Rushanovna Khabibullina * \\ Rishat Islamovich Shaikhiev ** \\ Damir Ravilyevich Salikhov ***
}

\section{Abstract}

This article discusses constitutional (statutory) electronic justice in the constituent entities of the Russian Federation as a method of organizing judicial activity based on information technologies, which aims to ensure the operation, mainly, of the principles of publicity and openness, transparency, and accessibility of information from constitutional (statutory) legal procedures as a variety of the latter in the Russian Federation. In the methodological of use the technique of documentary observation. Indeed, electronic (statutory)constitutional justice in the constituent entities of the Russian Federation has a multifaceted nature and characteristic, as it can be considered in several contexts, including the attribution to the group of additional constitutional guarantees of human and civil rights. It is concluded that electronic constitutional justice brings spaces of justice closer to individuals and communities, making it easier to exercise their rights and duties.

Keywords: principles of constitutional law; constitutional (statutory) courts; constitutional (statutory) justice; subjects of the Russian Federation; electronic justice.

* Gulnara Rushanovna Khabibullina, Kazan Federal University, Associate Professor of the Department of Constitutional and Administrative Law, Faculty of Law, KFU. ORCID ID: https://orcid.org/oooo0002-9024-5874. Email: gulnarakh@inbox.ru

** Rishat Islamovich Shaikhiev, Kazan Federal University, Postgraduate student of the Department of Constitutional and Administrative Law, Faculty of Law, KFU. ORCID ID: https://orcid.org/oooooo03-3598-2828. Email: sheih88@mail.ru

*** Damir Ravilyevich Salikhov, Lomonosov Moscow State University (MSU), Teaching Assistant of the Department of Constitutional and Municipal Law. ORCID ID: https://orcid.org/0000-0001-52471312. Email:d_salihov@law.msu.ru 


\section{Principios de derecho y justicia constitucional electrónica (estatutaria) en las entidades constitutivas de la Federación de Rusia}

\section{Resumen}

Este artículo analiza la justicia electrónica constitucional (estatutaria) en las entidades constitutivas de la Federación de Rusia como método de organización de la actividad judicial basada en las tecnologías de la información, que tiene por objetivo asegurar el funcionamiento, principalmente, de los principios de publicidad y apertura, transparencia y accesibilidad de la información de procedimientos legales constitucionales (estatutarios) como una variedad de estos últimos en la Federación de Rusia. En lo metodológico de empleo la técnica de la observación documental. En efecto, la justicia constitucional electrónica (estatutaria) en las entidades constitutivas de la Federación de Rusia tiene una naturaleza y características multifacética, ya que puede considerarse en varios contextos, incluida la atribución al grupo de garantías constitucionales adicionales de derechos humanos y civiles. Se concluye que, la justicia constitucional electrónica acerca los espacios de justicia a personas y comunidades, lo que facilita el ejercicio de sus derecho y deberes.

Palabras clave: principios de derecho constitucional; tribunales constitucionales (estatutarios); justicia constitucional (estatutaria); sujetos de la Federación de Rusia; justicia electrónica.

\section{Introduction}

The general idea of electronic justice as a kind of synthesis of the ongoing technological, legal and institutional changes in the information society and affecting material and procedural legislation does not disclose direct and reverse links between legal principles and processes of informatization of the judicial branch of government. The same can be noted in relation to the normative definition that discloses e-justice as a way of carrying out legal procedural actions based on information technologies in the activities of the judiciary, including their interaction with each other, as well as with individuals and legal entities in electronic (digital) form (Resolution of the Presidium of the Council of Judges of the Russian Federation, 2015).

At the same time, there is a different understanding of electronic justice, according to which the emergence of electronic tools has a direct impact on the implementation mechanism, first of all, of the constitutional principles of regulating the organization of legal proceedings. 
Gulnara Rushanovna Khabibullina, Rishat Islamovich Shaikhiev y Damir Ravilyevich Salikhov 614 Principles of Law and Electronic Constitutional (Statutory) Justice in the Constituent Entities of the Russian Federation

\section{Materials and Methods}

The work uses both general scientific methods of cognition (analysis, synthesis, generalization, comparison) and privatescientificmethods: formal legal, comparative legal, systemic and structural. The formal legal method of cognition makes it possible to establish the sources of consolidation of legal principles and norms that are significant for the organization of electronic constitutional (statutory) justice in the constituent parts of the federal state. The comparative legal research method is aimed at identifying general and specific signs of the formation of electronic justice in various subsystems of the judiciary, including the institution of specialized judicial constitutional control. The systemic-structural approach to the knowledge of electronic constitutional (statutory) justice allows us to determine its internal structure at this stage of the development of legal proceedings.

\section{Research Results}

Most of researchers consider that the aim of electronic justice as a method of organizing judicial activity based on information technology is to ensure the operation of the principles of openness, openness and accessibility of legal proceedings, openness and transparency of proceedings, openness, accessibility and transparency of legal proceedings (Globa, 2015), etc.

In addition, as some authors believe, the introduction of an electronic justice system has an impact on the traditional principles of legal proceedings, including the principle of equality of the parties (Isaeva, 2016), discretion, the principle of combining oral and written language of court proceedings, immediacy of court proceedings (Medimorec and Parycek, 2011).

However, information technologies affect not only the organizational and procedural principles of judicial activity; they also affect the foundations of the legal status of an individual (Serbena, 2015).

Thus, the legal literature notes that the informatization of justice should ensure the protection of human and civil rights and freedoms in the context of Article 18 of the Constitution of the Russian Federation (Rudneva and Kavkaeva, 2018).

The protection of human and civil rights and freedoms, having the status of a general principle of law and constitutional law is, on the one hand, one of the criteria of the principle of guaranteeing rights and freedoms, and on the other, the principle of their direct action, established constitutionally.

In turn, the principle of direct action of human and civil rights and freedoms, interpreted as a main, stable, fundamental requirement of an abstract, constituent and general nature, generalized expressing the basic laws of the formation, provision and unhindered realization of human 
rights, regardless of the presence of special conditions and procedures and implemented in legal relations on lawmaking in the field of human rights, realization and protection of human and civil rights and freedoms, acts, according to the Constitutional Court of the Russian Federation, one of the principles of the rule of law (Resolution of the Constitutional Court of the Russian Federation, 2004).

As for the principle of security of human and civil rights and freedoms, the informatization of judicial activity, as the experience of foreign countries with a decentralized judicial system shows (9), is designed to influence the mechanism of its implementation.

In this regard, the formation and development of electronic justice as a way of implementing constitutional (statutory) justice in the constituent entities of the Russian Federation, which can be considered in various aspects, including as an additional guarantee of ensuring and protecting human and civil rights and freedoms in the constitutional legal proceedings.

At the same time, this additional guarantee is of particular importance for the direct implementation of a number of constitutional rights and freedoms expressing the information freedom of an individual (the right to freely seek, receive, transfer, produce and distribute information in any legal way, the right to get acquainted with documents and materials affecting his rights and freedom, unless otherwise provided for by law, the right to apply personally, as well as to send individual and collective appeals to state bodies, which, within their competence, are obliged to consider these appeals, make decisions on them and give a reasoned response in accordance with the procedure established by law), which serves as the basis for other informational rights and freedoms.

The use of tools of electronic justice in the activities of constitutional (charter) courts is not limited to the recognition of its guaranteed nature. The fact is that the introduction of automated information systems and services in the procedures of constitutional proceedings means a significant expansion of the legal basis for the organization and operation of constitutional and statutory courts in the constituent entities of the Russian Federation by introducing acts of federal legislation into their composition.

We are talking primarily about the Federal Law No. 149-FZ of July 27, 2006 "On Information, Informatization and Protection of Information», which provides, inter alia, the right to receive information from a state body, its officials, concerning the rights, freedoms and duties of a person and a citizen, the denial of access to which can be appealed in court, Federal Law No. 262-FZ of December 22, 2008 «On Providing Access to Information on the Activities of Courts in the Russian Federation», securing the right of access to information on the activities of courts, without justifying the need to obtain the requested information about their activities, access 
Gulnara Rushanovna Khabibullina, Rishat Islamovich Shaikhiev y Damir Ravilyevich Salikhov Principles of Law and Electronic Constitutional (Statutory) Justice in the Constituent Entities of the Russian Federation

to which is not limited, the right to appeal in the prescribed manner the actions (inaction) of officials violating the right to access information on the activities of the courts and the established procedure for its implementation, Federal Law No. 63-FZ of April 6, 2011 «On Electronic Digital Signature», etc.

In addition, the introduction of the above federal laws into the legal framework for the organization and operation of constitutional and statutory courts means a complication of the system of principles that determine the organization of their internal activities, aimed at ensuring the formation of an electronic format of constitutional legal proceedings. In particular, the legislation of the constituent entities of the Russian Federation on constitutional (statutory) justice refers to such basic principles of providing access to information on the activities of constitutional and statutory courts, established by the federal legislator: openness and accessibility of information about their activities; reliability of information about their activities and its timely provision; freedom to search, receive, transfer and disseminate information about the activities of courts in any legal way; observance of the right of citizens to privacy, personal and family secrets, protection of their honor and business reputation; observance of the rights and legitimate interests of participants in legal proceedings, etc.

The transition to electronic constitutional (statutory) justice is not reduced to the emergence of new legal principles; it entails the need for a legal regulation of new social relations on their basis, and hence the appearance in the structure of the constitutional institution of regional specialized judicial constitutional control of additional legal education (subinstitution), which determines the access of subjects of appeal (complaint, request, petition) to court materials using information and communication technologies.

\section{Summary}

The use of information technologies in constitutional (charter) legal proceedings does not contradict the requirements of the Constitution of the Russian Federation, since, as the Constitutional Court of the Russian Federation believes, a constituent entity of the Russian Federation has the right, along with the basic guarantees of the rights of citizens enshrined in federal law, to establish in its law additional guarantees of these rights and freedoms aimed at specifying them, creating additional mechanisms for their implementation, taking into account regional characteristics (conditions) and in compliance with the constitutional requirements on the consistency of the laws of the constituent entities of the Russian Federation with federal laws and on the inadmissibility of restricting the rights and freedoms of a person and citizen in a form other than a federal law; implementing such legal regulation, the legislator of a constituent entity 
of the Russian Federation should not introduce procedures and conditions that distort the essence of certain constitutional rights, and reduce the level of their federal guarantees enshrined on the basis of the Constitution of the Russian Federation by federal law, as well as introduce any restrictions on constitutional rights and freedoms, since such - within the purposes and limits determined by the Constitution of the Russian Federation - can be established only by the federal legislator (Resolution of the Constitutional Court of the Russian Federation, 2012).

\section{Conclusion}

The elements that form the system of electronic constitutional (statutory) justice in the constituent entities of the Russian Federation include:

1) the presence of the official website of the constitutional and statutory court in the Internet with an indication of the e-mail address to which the user of the information can send his request;

2) posting of information on the activities of the constitutional and statutory court as part of the information portal of the constituent entity of the Russian Federation, which acts as a state information system that unites the official websites of state and local authorities on the Internet;

3) an electronic document as one of the legitimate forms of obtaining documented information about the activities of the constitutional and statutory court;

4) the creation of an electronic reception, as well as the possibility of submitting applications, requests and petitions in electronic form through the official website of the constitutional and statutory court in the Internet (for example, the Constitutional Court of the Republic of Tatarstan has the Rules for submitting applications in electronic form through the «Appeal to the Constitutional Court of the Republic of Tatarstan» in the «Feedback» section of the official website of the Constitutional Court of the Republic of Tatarstan);

5) broadcasting of open sessions on radio and television and in the Internet in the Statutory Court of the Sverdlovsk region;

6) placement in electronic form of information about cases in the proceedings of the constitutional and statutory courts, as well as about judicial acts adopted by the constitutional and statutory court (for example, according to republican legislation, it is subject to mandatory posting on the official website of the Constitutional Court of the Republic of Sakha (Yakutia) decisions, rulings and opinions, as well as messages on the state of constitutional legality in the Republic 
Gulnara Rushanovna Khabibullina, Rishat Islamovich Shaikhiev y Damir Ravilyevich Salikhov Principles of Law and Electronic Constitutional (Statutory) Justice in the Constituent Entities of the Russian Federation

of Sakha (Yakutia), data from judicial statistics on citizens' appeals for consideration of cases in the Constitutional Court of the Republic of Sakha (Yakutia));

7) information systems of the constitutional and statutory court (in particular, an information system has been created in the Statutory Court of the Kaliningrad region containing databases on laws and other regulatory legal acts of the Russian Federation, the Kaliningrad region and other constituent entities of the Russian Federation, decisions of the Statutory Court of the Kaliningrad region, decisions of the Constitutional courts of the Russian Federation and other constitutional (charter) courts of constituent entities of the Russian Federation);

8) electronic placement of samples of documents for appeal to the constitutional and statutory courts (in the Statutory Court of St. Petersburg - these are samples of complaints from citizens, requests for compliance with the Charter of St. Petersburg with laws and other regulatory legal acts of St. Petersburg, on the interpretation of the Charter of St. Petersburg);

9) electronic information on the procedure and schedule for personal reception of citizens by judges of the constitutional and statutory courts (on the official websites of the Constitutional Court of the Komi Republic and the Statutory Court of the Sverdlovsk Region).

Other elements of the system of electronic constitutional (statutory) justice in the constituent entities of the Russian Federation, practiced by constitutional and statutory courts, include maintaining an electronic archive of reviewed cases, electronic support for court proceedings and an electronic register of normative acts recognized by a constitutional or statutory court as inconsistent with the constitution or charter of a constituent entity of the Russian Federation.

\section{Acknowledgments}

The work is performed according to the Russian Government Program of Competitive Growth of Kazan Federal University.

\section{Bibliographic References}

FEDERAL LAW NO. 149-FZ. 2006. "On Information, Informatization and Protection of Information". Available online. In: http://flypods. $\mathrm{ru} / \mathrm{en} / 149$-fz-o-personalnyh-dannyh-zakon-ob-informacii-iinformacionnoi/. Consultation date: 05/12/2019. 
FEDERAL LAW NO. 262-FZ. 2008. "On Providing Access to Information on the Activities of Courts in the Russian Federation". Available online. In: http://www.informatica-juridica.com/legislacion/rusia/. Consultation date: $05 / 12 / 2019$.

FEDERAL LAW NO. 63-FZ. 2011. "On Electronic Digital Signature". Available online. In: https://www.global-regulation.com/translation/ russia/2942929/on-the-electronic-digital-signature.html. Consultation date: $05 / 12 / 2019$.

GLOBA, Victor V. 2015. “Electronic justice” In: International Scientific Journal «Innovative Science». Vol. 12, pp. 122-124.

ISAEVA, Klara Asangazyevna. 2016. Problems of realization of the principle of competitiveness and equality of rights in separate countries of the CIS at modern state. European science review. Available online. In: https:// cyberleninka.ru/article/n/problems-of-realization-of-the-principle-ofcompetitiveness-and-equality-of-rights-in-separate-countries-of-thecis-at-modern-stage. Consultation date: 05/12/2019.

MEDIMOREC, Daniel; PARYCEK, Peter. 2011. Vitalizing Democracy through E-Participation and Open Government: An Austrian and Eastern European Perspective. Available online. In: https://es.scribd.com/ document/110992215/Vitalizing-Democracy-through-E-participation. Consultation date: $05 / 12 / 2019$.

RESOLUTION OF THE CONSTITUTIONAL COURT OF THE RUSSIAN FEDERATIONNO.13-P. 2004. "On the case of verifying the constitutional nature of certain provisions of Articles 7, 15, 107, 234, and 450 of the Criminal Procedure Code of the Russian Federation in connection with the request of a group of State Duma deputies». Moscow, Russia.

RESOLUTION OF THE CONSTITUTIONAL COURT OF THE RUSSIAN FEDERATION NO. 19-P. 2012 "On the case of verifying the constitutionality of part 1 of Article 1, part 1 of Article 2 and Article 3 of the Federal Law "On the Procedure for Considering Applications of Citizens of the Russian Federation" in connection with the request of the Legislative Meetings of the Rostov region”. Moscow, Russia.

RESOLUTION OF THE PRESIDIUM OF THE COUNCIL OF JUDGES OF THE RUSSIAN FEDERATION NO. 439. 2015. The court informatization development concept until 2020. Moscow, Russia.

RUDNEVA, Iue Vai; KAVKAEVA, Iu Andria. 2018. "Electronic justice in civil procedure" In: International Journal Of Humanities And Natural Sciences. Vol. 1, No. 2, pp. 176-187.

SERBENA, Cesar Antonio. 2015. E-Justice and Governance: Collected Studies. Universidade Federal do Paraná (UFPR). Curitiba, Brazil 

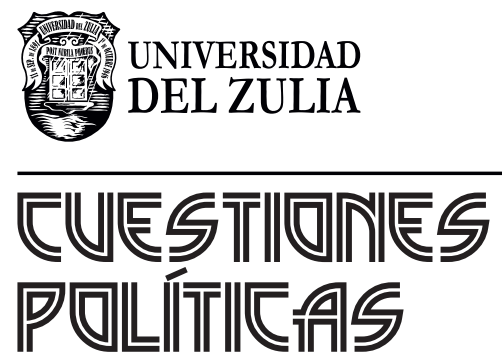

Vol.39 No 68

Esta revista fue editada en formato digital y publicada en enero de 2021, por el Fondo Editorial Serbiluz, Universidad del Zulia. Maracaibo-Venezuela 